Žarko Đorić, ${ }^{*}$

PhD Student,

Faculty of Economics, University of Niš
ПРЕГЛЕДНИ НАУЧНИ РАД

doi:10.5937/zrpfni1983251DJ

UDK: 321.7:330.34

Рад примљен: 30.03.2019.

Рад прихваћен: 02.07.2019.

\title{
THE RELATIONSHIP BETWEEN ECONOMIC DEVELOPMENT AND DEMOCRACY: LESSONS FOR TRANSITION COUNTRIES
}

\begin{abstract}
The key preoccupation and focus of the analytical attention of this paper is the consideration of the causative and consequential relations between the political and economic dimension of social life, that is, passing the boundary line between economy and politics. The major debate in this paper is: what is the causal relationship between democracy and economic development? When we are debating the Democracy-Development Nexus, the key finding of the analysis is reflected in the fact that, in spite of what the evidence in the scholarly literature is mixed and inconclusive, there is little disagreement that over time democracy and development are interdependent and mutually reinforcing. Although a strong positive link between the GDP per capita (key indicator of economic development) and the degree of development of the democratic structure in the case of selected transition economies has been confirmed, democracy, however, does not exclusively depend on the state of the economy, and economic weakness does not translate directly into the impossibility of democracy.
\end{abstract}

Key words: democracy, economic development, transition economies, democratic consolidation, middle-class.

\section{Introduction}

Although in the various spheres of social life - political and economic - the connection and relations of democracy and economy (the two fundamental forms of social reality) are almost inseparable. In the economic life, its institutions and forms, some principles of democracy have been imprinted: the principles of the general good, the principles of the freedom to choose economic alternatives and activities, the principles of property, markets, economic pluralism and the goals of economic activity (maximizing consumption, profit, income), and as such they "zdjoric82@gmail.com 
were came from the appropriate democratic institutions and represent their counterpart in the economic sphere.

The paper starts from the basic hypothesis which reads: When it comes to the relationship between democracy (democratic consolidation) and economic development, it is right to speak of their intertwining and interconnection. In addition, the work is also tested auxiliary hypothesis which reads as follows: There is significant positive relationship between higher GDP per capita levels (as conventional measure of economic development) and democracy scores in transition economies.

Work is structured in three interconnected entities. In the first part, the theoretical framework of the research was highlighted, while in the second part the research focus is directed towards the understanding of the mutual influence of democracy and economic development, as well as on the review of the selected literature in this field. In the third part, a review of the causal link between democracy (democratic consolidation) and economic development in the context of transition economies is given.

\section{Democracy and Economic Development - Theoretical Framework}

Democracy, as a theoretical concept, has long been the subject of deliberation and debate. However, it is very difficult to offer and accept the universal definition of democracy as it is difficult to determine its precise universal characteristics. According to Schumpeter (1947: 269) democracy is "institutional arrangement for arriving at political decisions in which individuals acquire the power to decide by means of a competitive struggle for the peoples vote". Economic development is a process by which nations improve the economic, political and social well-being of their people. Among others, higher economic development results in better people's health, better education, low unemployment and eradicating of poverty.

As one of the most important events in history, the rapid expansion of democracy is particularly characteristic for the second half of the $20^{\text {th }}$ century. As things stand today, democratic representative government is the most suitable means by which complex and developed contemporary societies can solve their social and other problems. In general, democracy is based on two closely related principles, which are: (1) public control over collective decision-making and (2) equality of rights in the application of that control. The degree to which these principles are exercised in practice determines to what extent a country is democratic or not (Jovičić, 2017: 53). Democracy, as the most common social system in the modern world, favours economic development because: 1 . stabilizes economic policy, 2 . offer a better long-term protection of property rights as 
well as individual and collective freedoms, 3. promotes the rule of law and free selection, 4. reduce corruption thanks to the stronger rule of law, 5 . lowers fiscal deficits and inflation, 6 . favours foreign investments, 7. makes development aid effective, 8. is more successful in managing social conflicts (or preventing politically powerful groups from monopolizing lucrative economic opportunities), 9. ensures political stability and preventing social disasters such as famine; 10 . enhance technical innovation and development of entrepreneurship (Carbone, 2008: 7; Ilan, Shaomin, Jun, 2016); Sharma, 2007: 40; Karakaya, Bulent Kantarcl, 2015: 1863, 1865; Fida, Zakaria, 2011: 67). It is believed that countries with low levels of corruption, strong property rights, independent judiciaries (Peev, Mueller, 2012: 372) and greater transparency and political accountability grow faster. Democracy can increase economic growth due to its positive effect on political stability, by reducing transaction costs, commitment constraints, and information asymmetries of political organization (Ruiz Pozuelo, Slipowitz, Vuletin, 2016: 2). Authoritarian regimes are considered to inhibit economic growth because, in comparison with democracies, it records higher military spending, which is then financed through tax increases (Sandalcilar, 2013: 65). On the other hand, multiparty competition may periodically cause risks to macroeconomic stability that are often associated with election cycles. Namely, the parties that are in power can get support by expanding fiscal costs before the key elections (result is a high budget deficit which may have destabilizing consequences), which will likely require a sharp reduction after the election. This is so called the "time-inconsistency problem" (see: Nova, 2011:4). "Political culture of adversarialism, and the short-termism encouraged by five-year electoral cycles, block effective responses to issues such as climate change, security, food systems, pensions and ageing" (Westall, 2015: 5).

By observing the developed countries of the West, it can be concluded that democracy is a valid economic regime. So democracy is not sufficient condition for a successful market economy, but it can be considered desirable from the standpoint of establishing a prosperous economic order (Prokopijević, 2000: 219). For a long time, it was generally believed that the economic development of a country depends on the degree of democracy that governs it. According to this theory, democracy guarantees political and civic freedoms and enables citizens and entrepreneurs to take the initiative, and these are important factors of development. It has, however, been shown that there are many examples of countries with an authoritarian regime that for a long period of time recorded significant economic growth. An example is China in the last two to three decades. Despite economic gains, China did not achieve political liberalization, and there is still in force capital controls, a fixed currency, government planning 
and heavy financial regulation. The key to success lies in political stability that provides a safe basis for economic development.

\section{Democracy and Economic Development - Mutual Effects and Literature Review}

The relationship between democracy and economic growth is not axiomatic and there are central three schools of thought when it comes to discussing the interrelationship between democracy and economic development:

(1) The "conflict school" - due to insufficient maturity of democracy state operations will be ineffective, undermining economic growth and development. The claim that non-democratic regimes are more economically viable is also known as "Lee hypothesis", according to Lee Kuan Yew, the former Prime Minister of Singapore. Within the framework of the conflict school, it is particularly pointed out the possibility of the proliferation of interest groups who then lobby for their own interests, thus slowing down the decision-making in the interests of society as a whole and causing stalemates in the political sphere. Olson (1982) is of the opinion that due to the search for rent by interest groups democracies with the flow of time are facing with so-called "institutional sclerosis". Certainly, the fact that one group is successful in one round of lobbying and pressure is an incentive for other groups that were losers in that round, and they try to use the benefits of themselves in the next round. It will again run other groups to reach their rents and thus to infinity. This problem could easily be solved through rules that are neutral to certain groups and which are protected by the great majority. Examples of the confirmation of the theoretical attitudes of the conflicting school stand out from present-day China and other Asian countries (so called "Asian tiger states") that record extremely high economic growth rates in conditions of low level of democracy. An illustrative example is Singapore, which is state poor in natural resources, but which is valid today as one of the economically the most powerful country in the world and as a hub for multinational companies, but which is politically authoritarian and in which the freedom of speech and expression is limited (for detail see: Joshua, 2018). Singapore is representative example how dictatorship and free market institutions can exist simultaneously.

(2) The "compatibility school" - within this theoretical perspective it points to system relationship on a relation politics-society-economy, and political pluralism in the sphere of governance results in economic pluralism that encourages growth. Through the affirmation of political and economic freedoms democracy guarantees property rights and market competitiveness, creating conditions for dynamic economic growth. 
(3) The "skeptical school" - within this school, emphasizes is that there is no relationship between democracy and economic growth, and that economic growth depends on whether economic policy measures are adequately designed or not. The skeptical school considers that the relation between democracy and economic development is not at all simple and it's hard to measure it.

The first author who empirically deal in his work on the correlation between higher levels of economic development and stability of democracy was Seymour Martin Lipset (Lipset, 1959), who, as a proponent of the theory of modernization, provides the first empirical test to prove that "democracy is related to the state of economic development" by correlating cross-national data on economic and democratic performance. Affirmation of democratic values in one society is induced by phenomena such as wealth, urbanization, education and industrialization. Especially level of education in society defines democratic development, whereby wealth and the middle class are crucial for the creation of extended educational opportunities. Especially, the improvement of the material and social conditions of the lower classes implies positive attitude towards democracy. On the other hand, economic development would also contribute to democracy by creating favorable conditions for the formation of a large number of voluntary associations which are promoting political participation. One of the most cited paper in this field is Barro (1996) who has come up with a very interesting model. Barro has demonstrated a political economic argument for the recently observed a non-linear, inverse U-shaped relation- the Barro-effect - between the level of democracy and economic performance where the initial benefits of democracy for economic growth are rapidly lost because of its expansion attention is directing to social programs through which redistribution of resources is carried out. Finally, extensive social programs produce restrictive effects on economic freedom that constrain investment and slow down economic growth (Barro, 1996: 3-4).

A high level of economic growth is not possible without high quality institutions. In this context, speaking of political institutions as the fundamental determinants of sustainable economic growth, Acemoglu and Robinson (2012) distinguish between inclusive and extractive political institutions. Democracy in formulation of "inclusive" institutions is a necessary condition for economic development. Inclusive institutions are those that need to be developed because of their positive effect on creativity, entrepreneurship, and various economic freedom as an important components for dynamic economic growth. On the other hand, extractive institutions have been created to satisfy the interests of political elites, and not the general population, with a negative effect on the development of inclusive economic institutions and society as a whole. Extractive political institutions may be able to generate economic growth, but at best only 
in the short term. Pereira \& Teles (2013) show that political institutions work as a substitute for democracy in promoting economic growth. In other words, political institutions are important for increasing economic growth, mainly when democracy is not consolidated.

Zaouali (2014) in his study discusses the relationship between economic growth, democracy and corruption, assessing the indirect effects of democracy on economic growth. A key finding is that one of the indirect benefits of democracy is its ability to reduce the negative effects of corruption on economic growth and prosperity. Farzanegan and Markwardt (2012) found that improvements in the democratic development of the MENA (the Middle East and North Africa) countries constitute a powerful weapon in solving environmental problems. The main conclusion is that these countries can benefit simultaneously from economic prosperity and environmental quality by "investing" in their political institutions and being accountable to their own electorates. This is an important implication for policymakers, bearing in mind that these countries are among the largest polluters in the world. Djezou (2014) examines the link between economic growth and democracy on the Côte d'Ivoire case for the period 1960 - 2012, where this country has gone through three decades of one-party (1960-1990) and two decades of multiparty (1990-2012). The key finding is that in the long run, in order for economic growth and democracy to be co-integrated, they must be linked to the durability of the regime, whereby economic growth, achieved through strong institutions, is a prerequisite for democratization. Baum and Lake (2003) deal with a statistical analysis of the direct and indirect effects of democracy on economic growth using a data set consisting of a 30-year panel of 128 countries. Instead of the statistically significant direct effects of democracy, the authors first discover that the effect of democracy is dominantly indirect and it is achieved through public health (an increase in life expectancy in poor countries) and education (strengthening secondary education in non-poor countries). Aisen and Jose Veiga (2011) use a dataset covering up to 169 countries in the period 1960 - 2004 and find that political instability (important aspect of democracy) has a strong adverse effects on total factor productivity growth and physical and human capital accumulation. Heshmati and Nam-Seok (2017) use panel data of 144 countries for period 1980-2014 and find credit guarantee as one of the most significant positive channel transmission between economic growth and democracy. Credit guarantee and foreign direct investment inflows manifest bigger marginal effects in democratic countries than in non-democratic countries. 


\section{The Relationship between Democracy and Economic Development - Empirical Issues}

Issues of democracy and development have an empirical manifestation and generally speaking, there are four propositions about this correlation in the vast literature that has attempted to interpret it: (a) the relationship between economic development and democratization is real, causal and positive; (b) the relationship between economic development and democratization is real, causal and negative; (c) the relationship between economic development and democratization is real but not causal; (d) the relationship between economic development and democratization is spurious (Cheibub, Vreeland, 2012).

Where are transitional economies? In transition economies, the question of the relationship between democracy, economic freedom and growth is particularly interesting. At the beginning of the transition process, economic freedoms were largely limited as a result of the communist regime. With a further process of democratization, different countries in transition record different degrees of economic freedom, which are strongly reflected on economic dynamics. Economic freedom is accelerating inclusive and sustainable growth by promoting productive activities and encouraging private initiatives and strengthening the entrepreneurial spirit. Nations with higher degrees of economic freedom prosper because they rationalize the regulatory environment, open the economy to greater competition, and fight against corruption (Miller, Kim, 2017: ix).

The scatter plot (see: Figure 1) between democracy (measured by EIU Democracy Index 2018) and economic development (measured by GDP per capita (PPP) \$) on the example of 15 transition economies $(10$ post-communist member-states of the European Union - Bulgaria, the Czech Republic, Estonia, Hungary, Latvia, Lithuania, Poland, Romania, the Slovak Republic and Slovenia and the 5 Western Balkans countries - Albania, Bosnia and Herzegovina, Macedonia, Montenegro and Serbia) shows a strong positive relationship and provide support for auxiliary hypothesis. 


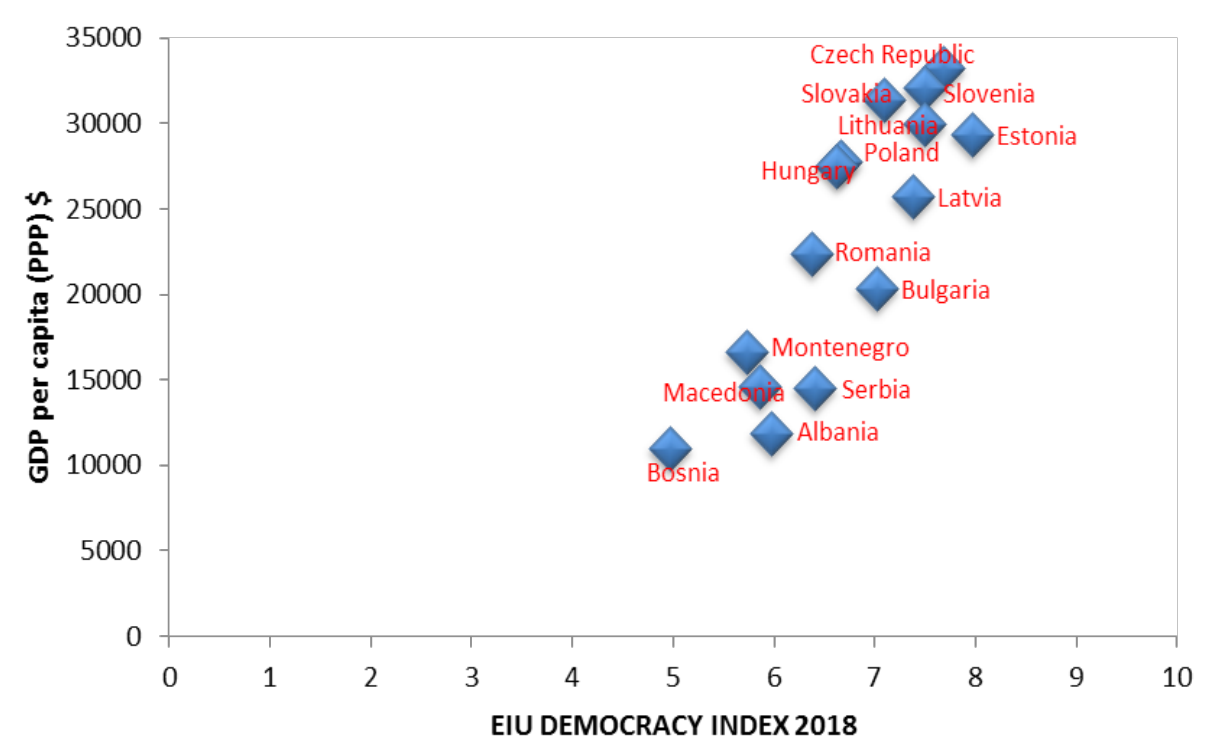

Figure 1. The Relationship between Democracy and Economic Development

Note: The Economist Intelligence Unit's Democracy Index is based on five categories: electoral process and pluralism; civil liberties; the functioning of government; political participation; and political culture. The index provides a snapshot of the current state of democracy worldwide for 165 independent states and two territories (almost the entire population of the world). The EIU Democracy index, as a measure of democracy, is on the scale of 0 to 10 . The index values are used to place countries within one of four types of regime: 1). Full democracies: scores of 8-10; 2). Flawed democracies: score of 6 to 7.9; 3). Hybrid regimes: scores of 4 to 5.9 ; 4) Authoritarian regimes: scores below 4.

Source: The Economist Intelligence Unit's Democracy Index 2018, Retrieved 10 February 2019, from: www.eiu.com/democracy2018 and for GDP per capita (PPP) see: Miller, T. Anthony B. K. Roberts, J.M. (2018 Index of Economic Freedom (Washington: The Heritage Foundation, 2018), Retrieved 22 March 2019, from: http:// www.heritage.org/index.

For transition countries it is useful to talk about democratic consolidation. Among the various theoretical approaches to the problem of consolidation of democracy, modern so-called structural theories put the greatest focus on socioeconomic development issues. In short, according to this approach, the chances for democracy depend on the level of economic development and modernization of society that are essential. In order to consider the relationship between 
democracy and modernization (economic development), Welzel and Inglehart (2008: 129-131) have emphasized the Human Empowerment Model (Figure 2) whose core is the claim that democracy can only be effective if power is given to people.

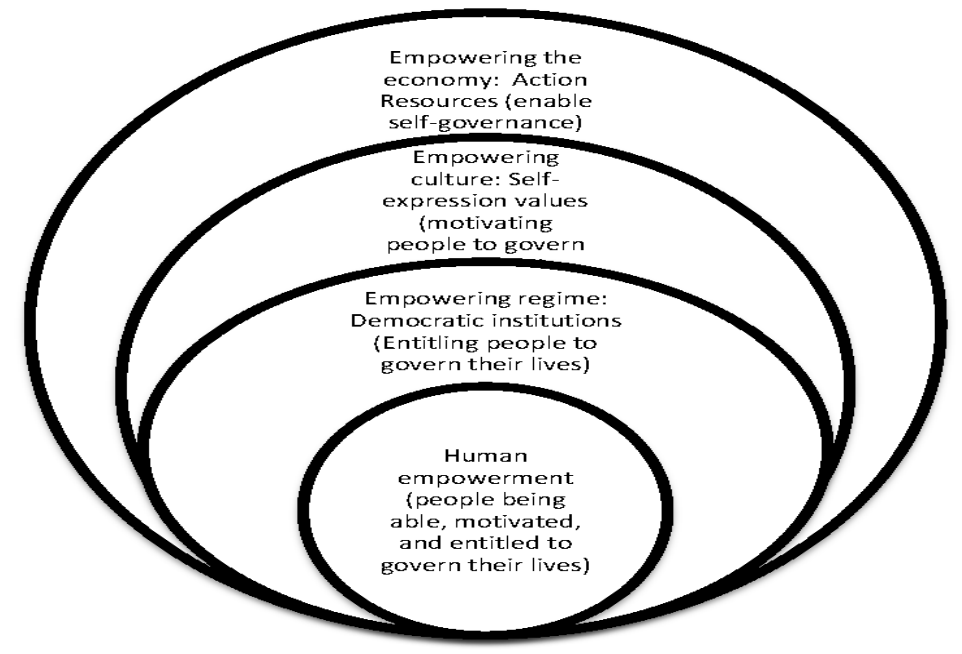

Figure 2. The Human Empowerment Model

Source: Welzel, Inglehart, 2008: 129

As democratic consolidation and economic development are two parallel, but at the same time, inevitable goals in this time, the strongest link, which could actually bring these two goals to one, is the recovery and consolidation of the middle stratum. The middle class together with better and widely accessible education is seen as the main promoter of democracy and the biggest stock of both democratic stabilization and economic development. A society dominated by a middle class is the most suitable environment for the development of democracy. In addition, in transition economies, democracy can be an incentive framework for faster implementation of the necessary structural reforms (Sandalcilar, 2013: 65). There is no doubt that some aspects of democratization have indeed shown positive correlation with economic growth (secure property rights, the rule of law, smaller government consumption, greater transparency and political accountability) (Nova, 2011: 8). About that, in the coming period the transition economies need to implement comprehensive reforms in key areas such as the rule of law, judicial reforms, the fight against corruption and organized crime, and public administration reform, which is crucial for the expansion of the private sector and therefore for economic development. Economic development is 
especially dependent on a well-functioning rule of law in the transition countries which means the absence of authoritarian, discretionary powers of the ruling political elite, stable and credible rules and an independent judiciary. A stable and credible legal framework creates a favorable environment for the initiative and creation of an individual, which is key to increasing economic efficiency. Weak rule of law and slow process of defining and allocating property rights (symptoms of insufficiently developed democracy) has contributed to the low level of investment and the unsustainability of economic growth. "The effectiveness of institutions and the soundness of democracy politics are acknowledged as catalysts for development. Democracy creates the enabling environment in which policy choices are subject to the control of free and responsible citizens capable of holding government and state institutions accountable for their implementation." (United Nations, 2013: 2). Corruption constitutes one of the major challenges to democratic development and open and transparent political structures in transition economies. Special attention should be paid to the factor of corruption, which destroys institutions in all transition countries, causes inefficient allocation of resources, reduces economic growth, productivity and has a negative impact on attracting foreign direct investment (FDI) (Jakopin, 2018: 95). The existence of corruption is considered a key reason for the low level of trust in democratic institutions and the failure of reform policy, resulting in slowed down economic development and the endangered standard of citizens, because tax revenues are reduced, and they increase public service expenditures and resources are redirected to private pockets. ${ }^{1}$ It takes into account the attitude that through the reduction of corruption democracy facilitates economic growth, given that due to the electoral mechanism, citizens can remove corrupt politicians or prevent them from engaging in corrupt actions and thus jeopardize their political survival (Drury et al., 2006). In countries where law and order (as the most important precondition for successful democratization) is strong enough, democratization stimulates economic growth, whereas in countries with poor law and order, democratization undermines growth by leading to the deterioration of the institutional capacities of the state as it undermines the effectiveness of government regulations. In addition if democratization occurs under the conditions of poor law and order then shadow economy expands, quality of governance worsens, and macroeconomic policy becomes less prudent, which makes it difficult to perform wise macroeconomic policy (low budget deficit and inflation) because the state is becoming hostage of industrial lobbies and populist groups (Polterovich, Popov, 2006: 9).

1 See: http://www.politika.rs/sr/clanak/57974/Percepcija-korupcije 


\section{Conclusion}

Although the relationship between democracy and economic development has many literature in the field of political science and economics, intercausal relations, magnitude of mutual influence and its structural determinants are still questionable. The question remains open to new reflections and research. Although in this paper the relationship between political regime and economic dynamics has been proven, an open question remains about the direction of the relationship. In terms of the relationship between democracy and economic development, there are no clear and unambiguous answers either in theory or in practice.

There is no development of democracy in one society until the standard of living is improved. It can be concluded that that democratic tendencies grew with the increase in the real social product per capita, the expected prolongation of life expectancy, and the lower gap in elementary education of women and men. However, this relationship between democracy and economic development can-not be represented as immediate and linear. Economic development, as an accompanying element of modernization, affects democratization, but it does not automatically create it; it is accelerating, but it is not guaranteed - as it is, after all, illustrated by the political history of the world. When considering the interaction between democracy and economic development, it is particularly important to take into account the specific nature of each country, i.e. structural factors such as the level of economic reforms, political history of the country, institutional heritage, ethics, cultural tradition, geographic factor and so on. Future research (qualitative or quantitative) would benefit from taking the impact of the economic crisis on democracy. It is believed that transitional democracy can experience a reversal primarily as a consequence of an economic recession (see: Svolik, 2008). The deteriorating economic situation caused by the global crisis has had wider consequences for the quality of democracy. The high unemployment, underdeveloped private sector, the huge influence of the political elite on the economy enhance clientelism, corruption and state capture.

As mentioned, the causality of economic development and democracy is insufficiently clear. Namely, for a long time it was generally believed that the economic development of a country depends on the degree of democracy which governs it. According to this theory, democracy guarantees political and civic freedoms and enables citizens and entrepreneurs to take the initiative, and these are important development factors. However, it has been shown that there are many examples of countries with an authoritarian regime that has recorded significant economic growth over the long term (Mexico between the 1940s and 1960s, or China 
in the last two to three decades, Ethiopia and Rwanda) ${ }^{2}$. Therefore, the general message would be that the key to success lies in political stability that provides a safe basis for economic development. Contrary, there are negative effects of political instability on a wide range of macroeconomic variables such as, among others, GDP growth, private investment, and inflation (Aisen, Jose Veiga, 2011).

For countries in transition, for the future of democracy and for the perspective of economic development the next phase is important when democracy should become "the only game in town" (Linz and Stepan) where economic development can no longer be discussed independently of democratic consolidation and the opposite about democratic stabilization regardless of the success of the reform, that is, regardless of the economic recovery and the new economic growth. What remains open is the question of how the transition economy should go in order to achieve the most optimal feedback of democratic and economic consolidation. Improving the political climate, political stability and good governance are extremely important for the democratic consolidation and future economic development of transition economies as a whole. In that sense, as a critical challenge for the development prospects of transition economies in the coming years is a need to recognized accountability and transparency, grounded in checks and balances especially on executive power.

\section{References}

Acemoglu, D. Robinson, J. (2012). Why Nations Fail: The Origins of Power, Prosperity and Poverty. New York: Crown.

Aisen, A., Jose Veiga, F. (2011). How Does Political Instability Affect Economic Growth?, IMF Working Paper, WP/11/12, 2010 International Monetary Fund.

Barro, R. J. (1996). Democracy and Growth. Journal of Economic Growth.1. 1-27.

Baum, M.A., Lake, D.A. (2003). The Political Economy of Growth: Democracy and Human Capital. American Journal of Political Science. Vol. 47, No. 2.333-347.

Carbone, G.M. (2008). Do all good things go together? Exploring the political, economic and social consequences of democratisation. Paper presented at the 66th Annual National Conference of the Midwest Political Science Association (MPSA), Chicago, 3-6 April 2008.

Cheibub, J.A. Vreeland, J.R. (2012). Economic Development, Democratization and Democracy. Paper presented at the $3^{\text {rd }}$ International Conference on Democracy as Idea and Practice, University of Oslo, January 12-13, 2012.

2 See: https://www.dw.com/sr/da-li-je-demokratijauslov-privrednog-uspeha/a-16592961 
Djezou, W.B. (2014). The Democracy and Economic Growth Nexus: Empirical Evidence from Côte d'Ivoire. The European Journal of Comparative Economics. Vol. 11, n. 2. 251-266.

Drury, A.C., Krieckhaus, J., Lusztig, M. (2006). Corruption, Democracy, and Economic Growth. International Political Science Review. Vol. 27, No. 2.121-136.

Farzanegan, M.R., Markwardt, G. (2012). Pollution, Economic Development and Democracy: Evidence from the MENA countries. Joint Discussion Paper Series in Economics. No 27-2012, Universität, Dep. of Business Administration \& Economics, Marburg.

Fida, B. Zakaria, M. (2011). Democracy and growth: a case study of Pakistan. International Journal of Economic Perspectives. vol. 5, no. 1. 67-82.

Heshmati, A., Nam-Seok, K. (2017). The Relationship between Economic Growth and Democracy: Alternative Representations of Technological Change, Discussion Paper series, IZA DP No. 10880, IZA - Institute of Labor Economics, JULY 2017.

http://www.politika.rs/sr/clanak/57974/Percepcija-korupcije

https://www.dw.com/sr/da-li-je-demokratijauslov-privrednog-uspeha/a-16592961

Ilan A. Shaomin, L. Jun, W. (2016). Corruption, Regime Type, and Economic Growth. Public Finance and Management. Volume 16, Number 4. 332-361.

Jakopin, E. (2018). Privredni rast i institucionalna tranzicija Republike Srbije. [Economic growth and institutional transition of the Republic of Serbia] Ekonomski horizonti. Maj - Avgust 2018, Volumen 20, Sveska 2. 95-108.

Joshua R. (2018). Authoritarian Institutions and Economic Growth: The Case of Singapore. Master Thesis. Lund University, School of Economic and Management.

Jovičić, D. (2017). Demokratija i Političke institucije. Civitas. 2017. 7(1). 50-64.

Karakaya, U. Bulent Kantarcı, H. (2015). The Relationship between Democracy, Freedom, and Economic Development. International Journal of Humanities and Social Sciences. Vol 9, No.6. 1863-1871.

Lipset, S. M. (1959). Some Social Requisites for Democracy: Economic Development and Political Legitimacy. The American Political Science Review. 53. 69-105.

Miller, T. Anthony B. K. Roberts, J.M. (2018 Index of Economic Freedom (Washington: The Heritage Foundation, 2018), Retrieved 22 March 2019, from: http:// www.heritage.org/index. 
Miller, T. Kim, A.B. (2017). Index of Economic Freedom (Washington: The Heritage Foundation, 2017), Retrieved 20 March 2018, from: http://www.heritage. org/index

Nova, E. (2011). Economic Crisis and Democratic Consolidation The Third Reverse Wave?. International Relations Quarterly. 2 (2). 1-9.

Olson, M. (1982). The Rise and Decline of Nations: Economic Growth, Stagflation, and Social Rigidities. Yale University Press, New Haven, CT.

Peev, E. Mueller, D.C. (2012). Democracy, Economic Freedom and Growth in Transition Economies. Kyklos. Vol. 65 - August 2012 - No. 3. 371-407.

Pereira, C., Teles, V.K. (2013). Are Political Institutions Substitutes for Democracy? A Political Economy Analysis of Economic Growth. Brazilian Review of Econometrics. v. 33, no 1. May 2013. 3-25.

Polterovich, V., Popov, V. (2006). Democratization, Quality of Institutions and Economic Growth. Working Paper \# 2006/056 - Moscow, New Economic School, 2006.

Prokopijević, M. (2000). Konstitucionalna ekonomija. [Constitutional Economy] Beograd: E Press.

Ruiz Pozuelo, J. Slipowitz, A. Vuletin, G. (2016). Democracy Does Not Cause Growth: The Importance of Endogeneity Arguments, IDB WORKING PAPER SERIES № IDB-WP-694, Inter-American Development Bank, Department of Research and Chief Economist, June 2016.

Sandalcilar, A.R. (2013). Democracy and Growth: Evidence from Transition Economies. American International Journal of Contemporary Research. Vol. 3 No. 1. 63-75.

Schumpeter, J.A. (1947). Capitalism, Socialism, and Democracy. $2^{\text {nd }}$ ed. New York: Harper \& Brothers.

Sharma, S.D. (2007). Democracy, Good Governance, and Economic Development. Taiwan Journal of Democracy. Volume 3, No.1, July 2007. 29-62.

Svolik, M. (2008). Authoritarian Reversals and Democratic Consolidation. American Political Science Review.Vol. 102, No. 2. May 2008. 153-168, doi:10.1017/ S0003055408080143.

The Economist Intelligence Unit's Democracy Index 2018, Retrieved 10 February 2019, from: www.eiu.com/democracy2018

United Nations, Democracy and Development: The Role of the UN, (2013), Discussion Paper, September 2013, ISBN: 978-91-86565-91-6. 
Welzel, C. Inglehart, R. (2008). The Role of Ordinary People in Democratization. Journal of Democracy. 19 (1). 126-140.

Westall, A. (2015). The Relationship between Democracy and Sustainable Development, Briefing, May 2015, Foundation for Democracy and Sustainable Development, Floor One, 51 Southwark St, London, SE1 1RU.

Zaouali, A. (2014). Corruption's and Democracy's Effects on Economic Growth. International Journal of Business, Economics and Management. 1(8). 186-200.

Жарко Ђорић, мастер економије

Докторанд Економског факултета Универзитета у Нишу

\section{Однос између економског развоја и демократије \\ - поуке за земље у транзицији \\ Резиме}

Кључна преокупација и фокус аналитичке пажње овог рада јесте разматрање узрочних и последичних односа између политичке и економске димензије друштвеног живота, односно прелазак границе између економије и политике. Главна дебата у овом раду јесте: каква је узрочна веза између демократије и економског развоја? Када расправљамо о концептуалној спони демократијаразвој кључни налаз анализе огледа се у чињеници да, упркос томе што су докази у научној литератури мешовити и у целини узев неубедљиви, мало је неслагања око тога да су током времена демократија и развој међусобно зависни и узајамно јачајући. Иако је потврђена снажна позитивна веза између ГДП пер цапита (кључни показатељ економског развоја) и степена развоја демократске структуре у случају одабраних транзиционих економија, демократија, међутим, не зависи искључиво од стања економије у држави, а економска слабост се не преводи директно у немогућност демократије.

Кључне речи: демократија, економски развој, транзиционе економије, демократска консолидација, средња класа. 
